\title{
Oxygen 15-labeled Carbon Monoxide
}

National Cancer Institute

\section{Source}

National Cancer Institute. Oxygen 15-labeled Carbon Monoxide. NCI Thesaurus. Code C119711.

A radiopharmaceutical comprised of oxygen-15 (150)-labeled carbon monoxide (150-

$\mathrm{CO}$ ) for use as a tracer molecule during positron emission tomography (PET). Upon inhalation, 150-CO binds to hemoglobin in the blood and the labeled red blood cells distribute evenly throug hout the vasculature in the body. Upon PET imaging, tissue blood volume can be quantified. 